\title{
Volume 30 Number 2
}

\section{5}

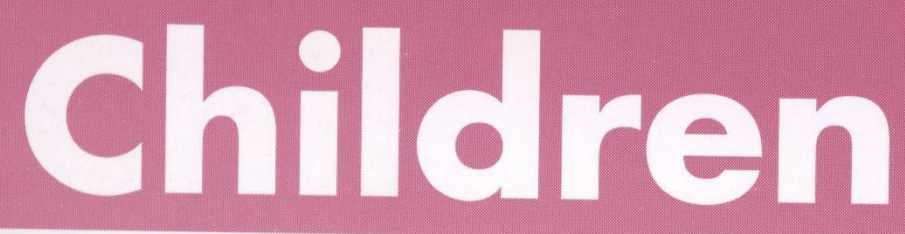

\section{Australia}

\section{$30^{\text {th }}$ year of publication \\ SPECIAL ISSUE}

In this issue ...

Children Australia : $30^{\text {th }}$ year of publication

Reflections on the past 30 years

Children Australia : Keeping us focused and connected

The reviewer speaks...

Beyond the continuum

New perspectives on the future of out-of-home care in Australia

Personal safety issues in the lives of children with learning disabilities

\section{CURRENT PERSPECTIVES ...}

The 'rule of optimism'

Dilemmas of embracing a strength based approach in child protection work

The 'quiet revolution' amongst men

Developing the practice of working with men in family relationships 


\section{Children Australia}

Volume 302005

Children Australia is a quarterly journal which aims to provide an opportunity for service providers, academics and others concerned with children and families to report on their work, to raise issues and to share their views.

The views expressed in Children Australia are those of the authors, and are therefore not necessarily endorsed by the Editors or members of the editorial board.

CO-EDITORS: Lloyd Owen

Dr Jennifer Lehmann

EDITORIAL ASSISTANT/SUBSCRIPTIONS:

Larraine Redshaw

c/-Oz Child: Children Australia

\section{SUBSCRIPTIONS 2005}

Standard [inc GST]

Student [inc GST].

Overseas Aus $\$ 85.00$

\section{ENQUIRIES}

For subscription enquiries, or to advise change of address, please contact:

Larraine Redshaw

Children Australia

PO Box 1312

South Melbourne

Vic 3205, Australia

Tel: [03] 96952200 Fax: [03] 96960507

Email: Iredshaw@ozchild.org.au

\section{GUIDELINES FOR CONTRIBUTORS}

Guidelines for those wishing to submit material to be considered for publication in Children Australia can be found on the inside of the back cover.

\section{NATIONAL EDITORIAL BOARD}

ACT

Dr Howard Bath

Director

The Thomas Wright Institute

NEW SOUTH WALES

Dr Elizabeth Fernandez

Senior Lecturer, School of Social Work

University of New South Wales

NORTHERN TERRITORY

Mrs Vicki O'Halloran

Chief Executive Officer

Somerville Community Services Inc.

QUEENSLAND

Ms Chris-Maree Sultmann

Encompass Family \& Community

SOUTH AUSTRALIA

Dr Freda Briggs

Emeritus Professor

University of South Australia

TASMANIA

Ms Scilla Sayer

Senior Policy Officer, Child \& Family Services

Department of Health \& Human Services

VICTORIA

Professor Chris Goddard

Interim Director

National Research Centre for the

Prevention of Child Abuse

Monash University

WESTERN AUSTRALIA

Dr David Vicary

Executive Director, Office for Children and Youth

EDITORIAL CONSULTANTS

Dr Frank Ainsworth

Research Scholar and Lecturer (Adjunct)

School of International Community \& Cultural Studies

Edith Cowan University

Associate Professor Margarita Frederico

Director, Post-graduate Programs

School of Social Work \& Social Policy

La Trobe University

\section{OZ CHILD REPRESENTATIVE}

Ms Susan Pitman

Senior Research Officer 


\section{$30^{\text {th }}$ year of publication \\ SPECIAL ISSUE}

\section{CONTENTS}

Editorial

Lloyd Owen

Children Australia : $30^{\text {th }}$ year of publication

- Reflections on the past 30 years Lloyd Owen

- Children Australia: Keeping us focused and connected. Lynda Campbell

- The reviewer speaks Jennifer Lehmann

Beyond the continuum

New perspectives on the future of out-of-home care in Australia

Paul Delfabbro, Alexandra Osborn and James G. Barber

Personal safety issues in the lives of children with learning disabilities

Freda Briggs and Russell Hawkins

CURRENT PERSPECTIVES ...

The 'rule of optimism'.

Dilemmas of embracing a strength based approach in child protection work

Carolyn Cousins

The 'quiet revolution' amongst men

Developing the practice of working with men in family relationships

Andrew King

Book reviews

The financial support of $\mathrm{Oz}$. Child: Children Australia is gratefully acknowledged

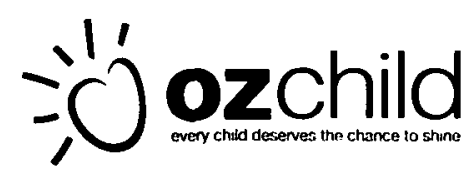

The financial support of the

La Trobe University Publications Committee is gratefully acknowledged 